\title{
УПРАВЛІННЯ ПРОЦЕСОМ САМОРОЗВИТКУ ПЕДАГОГА
}

Хлєбнікова Т. М., к.пед.н., доиент, Харківський наџіональний педагогічний університет імені Г. С. Сковороди;

Грінчук С. І., магістр, Управління освіти адміністраиій Київського району Харківської міської ради; Сльнікова М. П., магістр;

Шевченко О. М., магістр;

Украӥна, м. Харків

DOI: https://doi.org/10.31435/rsglobal_ws/31032019/6415

\section{ARTICLE INFO}

Received: 29 January 2019

Accepted: 20 March 2019

Published: 31 March 2019

\section{KEYWORDS}

self-development, professional self-development, management of self-development process,

complex-target program. \begin{abstract}
The article reveals the essence of concept "Pedagogues' selfdevelopment"; were analyzed theoretical aspects of pedagogues' selfdevelopment management, monitoring as mean of self-development management. The conducted monitoring research leads to the following conclusion: the teachers that took part in research have demand in selfdevelopment, eager to learn. It is found by the teachers that the main internal contradictions that arise in self-development activities are: no certainty that this will bring practical benefits $(38 \%)$; it is difficult to implement such activity practically (39\%). Uncertain in their ability to apply the knowledge gained as a result of self-education on practice $23 \%$ of teachers. According to the survey results, the most influential stimulating factors of self-development for teachers are: education, interest in the work, self-education and the possibility of gaining team's recognition. With help of qualimetrical approach it was determined that the management level of pedagogue's self-development - sufficient. The monitoring research allowed revealing the problems which became the basis of the complex-target program for improving of teachers' selfdevelopment management process.
\end{abstract}

Citation: Хлєбнікова Т. М., Грінчук С. І., Грінчук С. І., Шевченко О. М. (2019) Upravlinnia Protsesom Samorozvytku Pedahoha. World Science. 3(43), Vol.3. doi: 10.31435/rsglobal_ws/31032019/6415

Copyright: (C) 2019 Хлсбнікова Т. М., Грінчук С. І., Грінчук С. І., Шевченко О. М. This is an openaccess article distributed under the terms of the Creative Commons Attribution License (CC BY). The use, distribution or reproduction in other forums is permitted, provided the original author(s) or licensor are credited and that the original publication in this journal is cited, in accordance with accepted academic practice. No use, distribution or reproduction is permitted which does not comply with these terms.

Вступ. Зараз усе більш очевидним є те, що модернізація освіти вимагає актуалізації особистісного та професійного потенціалу педагогів. Саме включення педагога в самостійний, особистісно значущий процес професійного розвитку стає механізмом реальних змін у педагогічній практиці. Професійний розвиток особистості педагога триває протягом усього життя. На кожному етапі він наповнюється новими потребами, а отже, і новим змістом, новими організаційно-педагогічними формами й методами та відповідними підходами до інтегрування індивідуальних професійних, соціальних аспектів життєдіяльності. Саморозвиток як форма розвитку, за якої особистість займає активно-творчу позицію по відношенню до своїх змін, стає сьогодні провідним способом становлення особистості, позначаючи перед керівництвом закладу освіти завдання осягнення його сутності, механізмів, умов, засобів здійснення.

У науковій літературі $[3,4]$ саморозвиток розглядають як соціальний, особистісний i духовний феномен. Він безпосередньо пов'язаний із усвідомленням особистістю своєї цінності й унікальності та сприяє розвитку діяльності, яка спрямована на самого себе 3 метою позитивних самозмін і наближення до «Я-ідеального». Ми поділяємо точку зору Е. Ісаєва [1], 
який уважає, що поняття «саморозвиток»- це фундаментальна здатність людини ставати й бути справжнім суб'єктом свого життя, перетворювати власну життєдіяльність у предмет практичного перетворення. У нашому баченні діяльність педагога висуває потребу у двох видах саморозвитку; перший - удосконалення своїх знань і вмінь у різноманітних галузях діяльності, безпосередньо не пов'язаними з його педагогічною діяльністю, а також другий вид, що переслідує мету розвитку й удосконалення знань і вмінь, необхідних для його безпосередньої діяльності й підвищення майстерності [11].

На основі аналізу напрацювань О. Слободян [5] доходимо висновку, що саморозвиток особистості базується на таких положеннях:

- сприяє самовдосконаленню, самореалізації особистості;

- має діяльний характер;

- внутрішніми стимулами розвитку особистості є іï потреби, мотиви, інтереси й установки;

- основою формування потреб, мотивів, інтересів та установок особистості $\epsilon$ внутрішні суперечності, які стимулюють активність особистості, сприяють іiі саморозвитку;

- зовнішніми факторами саморозвитку особистості $\epsilon$ впливи середовища та цілеспрямоване виховання;

- саморозвиток особистості - це не самовільний, спонтанний процес.

Отже, забезпечення управління процесом саморозвитку, яке реалізується на основі комплексного підходу, планомірності, систематичності, послідовності саморозвитку, зв’язку саморозвитку з практичною діяльністю, поєднання індивідуальної роботи із саморозвитку 3 діяльністю педагогічного колективу, поетапної завершеності роботи із саморозвитку, сприяє ефективності професійного зростання педагога.

Метою цієї роботи є обгрунтування необхідності управління процесом саморозвитку педагога.

Результати дослідження. Ефективність саморозвитку педагогів залежить від якості управління цим процесом, яке передбачає створення умов для формування й розвитку потреби в прагненні до самоосвіти, самореалізації. Управління процесом саморозвитку педагога - це цілеспрямована діяльність, що є наслідком глибокого вивчення й аналізу змісту, методів і форм організації самоосвіти педагогів, постійний моніторинг діяльності педагогів із зазначеної діяльності.

Дослідження проводили на базі шкіл Новобоварського та Київського районів м. Харкова. У дослідженні брали участь 3 групи педагогів, педагогічний стаж, яких від 1 року до 5 років (1-а група), 2-а група - учителі, педагогічний стаж яких від 6 років до 15 років, 3-я група - педагоги зі стажем роботи від 16 до 25 років.

Аналізуючи отримані результати, можна зазначити, що тільки 46 \% учителів знаходяться на стадії активного саморозвитку, у $32 \%$ - відсутня стійка система саморозвитку, $22 \%$ - знаходяться в стані саморозвитку, що зупинився. При цьому необхідно зазначити, що $56 \%$ педагогів першої групи знаходяться на стадії активного саморозвитку, педагогів другої групи - 42 \%, а педагогів третьої групи - 26 \%. Крім того, достатній саморозвиток або відсутня стійка система саморозвитку в 44 \% учителів першої групи, 36 \% вчителів другої групи та 25 \% - третьої групи. Також з'ясовано, що на стадії зупиненого саморозвитку знаходяться $49 \%$ педагогів третьої групи та $22 \%$ педагогів другої групи, а от серед педагогів першої групи таких немає.

Найбільше впливовими стимулюючими факторами саморозвитку для педагогів є: навчання, інтерес до роботи, заняття самоосвітою, можливість отримати визнання в колективі. Серед факторів, які перешкоджають саморозвитку, були виділені: обмежені ресурси та скрутні життєві ситуації, розчарування в результаті невдач, відсутність підтримки, слабка навчальноматеріальна база, формалізм вимог адміністрації, необ'єктивна оцінка з боку адміністрації, відсутність інформації про об’єктивні інноваційні технології, відсутність в учнів бажання вчитися, надмірна регламентація роботи вчителя з боку адміністрації.

Основними внутрішніми суперечностями, які виникають в діяльності із саморозвитку, вчителі вважають такі: бракує впевненості, що це принесе практичну користь (38 \%), важко таку діяльність реалізувати практично (39\%). Невпевнені у своїх можливостях застосовувати знання, отримані в результаті самоосвіти, у практичній діяльності 23 \% педагогів.

Нами було проаналізовано ефективність діяльності вчителів із саморозвитку. Із цією метою використали кваліметричну модель, у якій було виділено такі параметри: мотиваційноціннісний, діяльнісний, підсумково-результативний. Отримані результати наводимо в табл. 1. 
Таблиця 1. Результати аналізу ефективності діяльності педагогів із саморозвитку

\begin{tabular}{|c|c|c|c|c|}
\hline \multirow{2}{*}{$\begin{array}{l}\text { Рівні самоосвітньої } \\
\text { діяльності }\end{array}$} & \multicolumn{3}{|c|}{ Параметри } & \multirow{2}{*}{$\begin{array}{l}\text { Середнє } \\
\text { значення у \% }\end{array}$} \\
\hline & $\begin{array}{c}\text { Мотиваційно- } \\
\text { ціннісний }\end{array}$ & Діяльнісний & $\begin{array}{c}\text { Підсумково- } \\
\text { результативний }\end{array}$ & \\
\hline Оптимальний & $37 \%$ & $40 \%$ & $43 \%$ & $40 \%$ \\
\hline Достатній & $52 \%$ & $52 \%$ & $40 \%$ & $48 \%$ \\
\hline Недостатній & $11 \%$ & $8 \%$ & $17 \%$ & $12 \%$ \\
\hline
\end{tabular}

Мотивація як система мотивів або стимулів, що спонукає людину до конкретних форм діяльності, поведінки, яка виступає у формі уявлень, ідей, почуттів, переживання, виражають матеріальні або духовні потреби людини, є важливим фактором у діагностиці вчителів.

Вивчаючи мотивацію вчителів до саморозвитку, нами були виділені на основі підходу А. Маркової, Т. Матіс, О. Орлова [6; с. 69-74] мотиви навчання, мета навчання, емоції, які переживає вчитель. Було визначено, що 3,6 \% із 210 вчителів із негативним ставленням до навчання мають низький рівень знань, їх навчальна діяльність не сформована. Переважає мотив ухилення від неприємностей, відсутній інтерес до процесу та змісту учіння. Свої невдачі вчителі пояснюють зовнішніми факторами. Для цієї групи вчителів характерні емоції запобігання, стійкої невпевненості в собі, незадоволеності собою та викладачем.

$17,1 \%$ педагогів виявляють нейтральне ставлення до навчання, для них характерні нестійкі мотиви інтересу до результатів учіння, реалізуючи мету навчання, вони ухиляються від труднощів, не повертаються до невирішених задач, для них характерні негативні емоції невпевненості.

Позитивне ставлення до навчання можна характеризувати як ситуативне, усвідомлене, активне й відповідальне. Ситуативне ставлення характерно для 35,6 \% вчителів експериментальних груп, воно характеризується широким пізнавальним мотивом (інтересом) до результату учіння й до оцінки, високим рівнем мотиву відповідальності. Під час реалізації мети навчання вчителі орієнтуються на результат своєї діяльності, переважають нестійкі позитивні емоції, які залежать від ситуації й тому, залежно від ситуації, коли переважають позитивні емоції, ситуативне ставлення може бути ситуативно-активним, а у випадку співвідношення мотивів і мети, яку висувають із урахуванням суб'єктивної ймовірності успіху, ставлення до навчання стає ситуативно-усвідомленим. Рівень знань учителів достатній, під час навчальної діяльності вони розуміють і виконують навчальну задачу.

20,5\% вчителів експериментальних груп мають усвідомлене ставлення до навчання, яке характеризується самостійно поставленою метою, отже, і новими мотивами. Мотиви й мета співвідносяться зі своїми діями. Мету формулюють із урахуванням суб'єктивної ймовірності успіху. Учитель уміє визначати час на досягнення мети, пояснює свої успіхи й невдачі як об'єктивними труднощами, так і своїми зусиллями в розв'язанні проблеми. Характерними $\epsilon$ негативні емоції тимчасової незадоволеності собою в разі зіткнення із задачею нової складності. Рівень знань учителів достатній, під час навчальної діяльності вони самостійно переходять від одного етапу до наступного, усвідомлено шукають різні способи розв'язання навчальної задачі.

Для 16,2 \% вчителів експериментальних груп характерно активне, творче ставлення до навчання, якому властиві мотиви вдосконалення способів навчально-пізнавальної діяльності. Вони усвідомлено співвідносять свої мотиви й мету. Мету ставлять перспективну, відстрочену, змінюють залежно від ситуації. Переважають позитивні емоції в процесі формулювання нестереотипної мети, емоції конструктивного сумніву. Рівень знань високий, характерна гнучкість, мобільність способів навчальної діяльності.

Відповідальне ставлення, а таких учителів 7,1\% в експериментальних групах, характеризується мотивами вдосконалення способів співробітництва з іншими в ході навчальнопізнавальної діяльності, мотивами відповідальності на основі причетності до результатів спільної діяльності. Слухачам властиве підпорядкування мотивів, їх стійка ієрархія з домінуванням одного, двох мотивів. Наявні позитивні емоції особистісного упередженого ставлення до ходу й результатів учіння, впевненості у своїх можливостях, активної позиції в колективі, вибіркові особистісно забарвлені емоції, позитивні й негативні емоції співпереживання.

Відповідно до певних ставлень були виділені такі рівні мотивації: високий рівень (Е-1 $52,2 \%$, E-2 - 40,4 \%, Е-3 - 54,8 \%) - йому відповідає усвідомлене ставлення до навчання, активне й відповідальне; середньому рівню (Е-1 - 47,8 \%, Е-2 - 55,8 \%, Е-3 - $42 \%$ ) - нейтральне, ситуативне; 
низькому рівню (E-1 - 0 \%, E-2 - 3,8 \%, E-3 - 3,2 \%) - негативне ставлення до навчання.

Із метою оцінювання якості управління саморозвитком педагога нами було використано кваліметричну модель [11]. Були визначені параметри оцінки:

- аналітична діяльність (як критерії були визначені: наявність і рівень системи інформаційного забезпечення управління саморозвитком педагога, аналіз можливостей педагогічного колективу до саморозвитку, аналіз результатів експертизи управління саморозвитком педагога);

- планово-прогностична діяльність (критерії: прогнозування потреб педагога в саморозвитку, прогнозування наслідків управління саморозвитком педагога, планування етапів управління саморозвитком педагога);

- організаційна діяльність (критерії: організація творчих і проблемних груп, які сприяють саморозвитку педагога, організація заходів із підвищення професійної компетенції педагогів, організація системи мотивації та стимулювання діяльності, спрямованої на саморозвиток);

- координаційна діяльність (критерії: координація діяльності учасників освітнього процесу з проблеми саморозвитку);

- контролююча діяльність (критерії: контроль за стимуляцією до саморозвитку, контроль відповідності процесу меті, завданням і результатам, контроль за стимуляцією до саморозвитку).

Оцінку здійснювала експертна група у складі 9 осіб, магістрів з управління закладами освіти. Отримані результати наводимо в табл. 2.

Таблиця 2. Експертна оцінка якості управління саморозвитком педагога

\begin{tabular}{|l|c|c|c|c|c|c|c|c|c|c|}
\hline \multirow{2}{*}{ Параметри } & \multicolumn{10}{|c|}{ Експертна оцінка } \\
\cline { 2 - 12 } & $\mathrm{E}_{1}$ & $\mathrm{E}_{2}$ & $\mathrm{E}_{3}$ & $\mathrm{E}_{4}$ & $\mathrm{E}_{5}$ & $\mathrm{E}_{6}$ & $\mathrm{E}_{7}$ & $\mathrm{E}_{8}$ & $\mathrm{E}_{9}$ & Сер.знач. \\
\hline 1. Аналітична діяльність & 0,12 & 0,11 & 0,13 & 0,12 & 0,13 & 0,12 & 0,12 & 0,13 & 0,14 & 0,12 \\
\hline $\begin{array}{l}\text { 2. Планово-прогностична } \\
\text { діяльність }\end{array}$ & 0,1 & 0,1 & 0,1 & 0,1 & 0,2 & 0,1 & 0,1 & 0,2 & 0,1 & 0,12 \\
\hline 3. Організаційна діяльність & 0,15 & 0,16 & 0,14 & 0,16 & 0,15 & 0,15 & 0,16 & 0,12 & 0,13 & 0,15 \\
\hline $\begin{array}{l}\text { 4. Координаційна } \\
\text { діяльність }\end{array}$ & 0,3 & 0,2 & 0,2 & 0,1 & 0,1 & 0,2 & 0,2 & 0,2 & 0,2 & 0,19 \\
\hline $\begin{array}{l}\text { 5. Контролююча } \\
\text { діяльність }\end{array}$ & 0,19 & 0,18 & 0,18 & 0,15 & 0,15 & 0,17 & 0,16 & 0,16 & 0,15 & 0,17 \\
\hline Сер. значення & 0,86 & 0,75 & 0,75 & 0,63 & 0,73 & 0,74 & 0,74 & 0,81 & 0,72 & 0,75 \\
\hline
\end{tabular}

Загальний рівень управління процесом саморозвитку педагога виражається сумою параметрів: $\mathrm{P}_{3}$ Г $=\mathrm{P}_{1}+\mathrm{P}_{2}+\mathrm{P}_{3}+\mathrm{P}_{4}+\mathrm{P}_{5}$.

Якщо $0<$ Рзаг $\leq 0,5-$ рівень недостатній; $0,6<$ Рзаг $\leq 0,75-$ рівень достатній (допустимий); 0,76 $<$ Рзаг $\leq 1-$ рівень оптимальний.

Рзаг $=0,12+0,12+0,15+0,19+0,17=0,75$.

Управління процесом саморозвитку педагога знаходиться на достатньому (допустимому) рівні.

На основі аналізу було виявлено проблеми й недоліки: рівень системи інформаційного забезпечення управління саморозвитком педагога недостатній; недостатній аналіз можливостей педагогічного колективу до саморозвитку; немає прогнозування потреб педагога в саморозвитку; існує потреба в плануванні етапів управління саморозвитком педагога, не створено творчих і проблемних груп, які би сприяли саморозвитку педагога, потрібна координація діяльності учасників освітнього процесу з проблеми саморозвитку, контроль за стимуляцією до саморозвитку недостатній.

Виявлені проблеми стали підгрунтям для розробляння комплексно-цільової програми.

Спираючись на роботи В. Зверєвої [2], П. Третьякова [8], ми розробили комплексноцільову програму «Удосконалення управління процесом саморозвитку особистості педагога».

Проблема: невідповідність між реальним станом управління процесом саморозвитку педагогів та його необхідним рівнем.

Мета: створити умови для ефективного управління процесом саморозвитку педагогів.

Структура розробленої програми включає: систему необхідних форм і заходів організації роботи, основний зміст діяльності, етапи діяльності, поточний і підсумковий аналіз, контроль, 
регулювання, корекцію результатів. Програма розрахована на один рік і складається 3 4-х етапів: інформаційно-аналітичний (серпень-вересень), мотиваційно-цільовий (жовтень-січень), організаційно-виконавчий (лютий-квітень), регуляційно-корекційний (травень-червень).

Висновки. Отже, управлінський супровід педагога в процесі саморозвитку вимагає забезпечення необхідних для цього об'єктивних і суб'єктивних факторів. Перспективним напрямом подальшого дослідження вважаємо впровадження цільового проекту з удосконалення управління процесом саморозвитку вчителя в періоди вікових криз професійного становлення.

\section{ЛІТЕРАТУРА}

1. Исаев Е. И. Становление и развитие профессионального сознания будущего педагога / Е. И. Исаев, С. Г. Косарецкий, В. И. Слободчиков // Вопросы психологии. — 2000. — № 3. — С. 57-66.

2. Зверева В. И. Организационно-педагогическая деятельность руководителя школы / В. И. Зверева. Москва: Новая шк., $1997-320$ с.

3. Костенко М. А. Педагогічні умови професійно-творчого саморозвитку майбутнього вчителя : дис. на здоб. наук. ступеня канд. пед. наук : спец. 13.00.04 - теор. та метод. проф. осв. / Костенко Маріанна Артурівна. - Харків, 2004. - 180 с.

4. Кузікова С. Б. Психологічні основи становлення суб'єкта саморозвитку в юнацькому віці : [монографія] / С. Б. Кузікова. - Суми : Мак Ден, 2012. - 410 с.

5. Слободян О. П. Творчий саморозвиток особистості студентів педагогічного коледжу в процесі вивчення культурологічних дисциплін / О. П. Слободян. - Луцьк, 2004. - 205 с.

6. Маркова А. К. Формирование мотивации учения / А. К. Маркова, Т. Н. Матис, А. Б. Орлов. Москва: Просвещение, 1990. - 192 с. — (Психологическая наука - школе).

7. Маркова А. К. Психологические проблемы повышения квалификации / А. К. Маркова // Педагогика. - 1992. — № 9-10. - С. 65-67.

8. Третьяков П. И. Управление школой по результатам. Практика педагогического менеджмента / П. И. Третьяков. - Москва : Новая шк., 1997. — 288 с.

9. Хлєбнікова Т. М. Діагностика успішності вчителя / Т. М. Хлєбнікова // Управління школою. 2004. 一№ 12. - C. $2-8$.

10. Хлєбнікова Т. М. Управління навчальною діяльністю : [навч.-метод. посіб. для виклад., слухачів ІПО] / Т. М. Хлєбнікова. - Харків : Основа, 2013. — 224 с.

11. Хлєбнікова Т. М. Акмеологічний супровід педагога в процесі саморозвитку / Т. М. Хлєбнікова, О. Є. Гречаник, В. В. Григораш // Science Review. — № 6 (13). — July, 2018. — Vol. 1. 